\title{
Vegetation Database of Iran
}

\author{
Alireza Naqinezhad
}

\begin{abstract}
Iran is a large country with a total surface of $1,648,000 \mathrm{~km}^{2}$ and altitude ranging from $25 \mathrm{~m}$ b.s.l. along the Caspian Lowlands to 5,774 $\mathrm{m}$ a.s.l. on Mt. Damavand. The climatic conditions within the country are very diverse with a climate ranging from less than $100 \mathrm{~mm}$ mean annual precipitation in the central deserts of Iran up to more than 2,000 $\mathrm{mm}$ in the north of Iran. The climate contrasts together with different geological substrates across the country providing various habitats and vegetation structures. By now, there is no comprehensive vegetation database dealing with all regions of Iran. There is only scattered vegetation information mainly for the forest areas and the halophytic vegetation. The mountain steppes, wetlands and Zagros Mountains remain still unknown. The Vegetation Database of Iran (GIVD ID AS-IR-001) has been planned for collecting all available literature on Iranian vegetation and continues future input to the database.
\end{abstract}

Keywords: Alborz; Caspian; Hyrcanian forest; relevé.

\section{Vegetation Database of Iran}

Scope: This database includes the large plot data from different parts of Iran, mainly Hyrcanian forests and mountain vegetation. It will be further extended to other parts of Iran.
Status: emerging
Period: $1930-2012$

Database manager(s): Alireza Naqinezhad (a.naqinezhad@umz.ac.ir)

Owner: Alireza Naqinezhad (private)

Web address: [NA]

Availability: after blocking period

Database format(s): Excel

Publication: [NA]

Plot type(s): normal plots

Non-overlapping plots: 2,000

Total plot observations: 2,000

Countries: IR: $100.0 \%$

Forest: [NA] - Non-forest: [NA]

Guilds: all vascular plants: $100 \%$

Environmental data: [NA]

Performance measure(s): [NA]

Geographic localisation: [NA]

Sampling periods: [NA]

Information as of 2012-07-12; further details and future updates available from http://www.givd.info/ID/AS-IR-001

Alireza Naqinezhad (a.naqinezhad@umz.ac.ir)

Department of Biology, Faculty of Basic Sciences, University of Mazandaran, Babolsar, IRAN. 